\title{
INNOVATION AT AIRPORTS: A SYSTEMATIC LITERATURE REVIEW (2000-2019)
}

\author{
Sena KILIÇ, Caglar UCLER, Luis MARTIN-DOMINGO \\ Faculty of Aviation and Aeronautical Sciences, Ozyegin University, Istanbul, Turkey
}

Received 24 July 2020; accepted 30 December 2020

\begin{abstract}
Airports operate in a highly-competitive and challenging environment. Therefore, in order to remain competitive, innovation is imperative for airports. This paper aims to conduct academic research into innovation at airports by reviewing studies published from 2000 to 2019 for presenting key findings. A systematic literature review was made based on scientific papers indexed in Scopus with the keywords innovation and airport in the title, abstract or keywords sections, consolidating the innovation focus, approach and degree discussed with respect to innovation areas and territorial focal points. Consequently, it was found that research on airport innovation is: (i) mainly focused on products/services, (ii) concerned with leveraging ICT (Information Communication Technology), (iii) implemented ad-hoc without a consolidated strategic approach, and (iv) lacks the input of external innovation scholars and specialists.
\end{abstract}

Keywords: airport, innovation, literature review, ICT, airport design, performance measurement.

\section{Introduction}

The air transportation industry is continuously changing (Chambers, 2007) with a rapid growth in both traffic and passenger expectations. Then, consumer trends, security developments and political changes have made air transportation even more challenging (Graham, 2009), where airports have a significant role. They are one of the enablers of this industry and have essential impact on regional wealth, employment opportunities and economic development (Graham, 2013). So, the success and continuous growth of airports are vitally important. Consequently, they need to upgrade themselves to introduce new products, services, processes, strategies and business models to remain competitive, which can be achieved by innovation (Humphrey \& Schmitz, 2002).

Innovation is the added value generation (Jacobides et al., 2006) by new ideas, methods, or devices (MerriamWebster, 2017). It is about the interaction of technology, market and organization, where competitive advantage can be achieved by generation and delivery of new product and service offerings (Tidd \& Bessant, 2013). Today, companies invest a considerable amount of resources into it (Stock \& Zacharias, 2011).

Many innovation efforts focus on new offerings (Jacobides et al., 2006), but there is a new focal shift in innovation practices from products and services towards co- created value, i.e. the experience (Prahalad \& Ramaswamy, 2003). Then, the value is also delivered by subject innovation in business processes (Organisation for Economic Cooperation and Development [OECD], 2005) or business model innovation (Amit \& Zott, 2012). OECD (2018) defines beside product and process innovation also organizational, and marketing innovation. Consequently, airports have to internalize and practice all types of innovation, delivering new offerings, processes and high quality passenger experience, which particularly utilizes also new processes or technologies.

Despite the increasing focus of industry and academia on innovation in general, there is no research specifically focusing on the question how innovation can be achieved at airports. This study provides an extensive overview of academic research into innovation at airports to further quantify innovation examples with respect to areas of interest and types of innovation. So, the main purpose of the study is to examine studies conducted on airport innovation and to divide them into different categories accordingly how they address innovation, thereby determining the direction of innovation studies and practices. This study contributes to the existing literature by extending airport-innovation research framework for classification and identifying areas for future research. Besides, it makes contributions to practitioners by providing a practical guide in airport innovations.

*Corresponding author. E-mail: sena.kilic@ozyegin.edu.tr

Copyright $\odot 2021$ The Author(s). Published by Vilnius Gediminas Technical University

This is an Open Access article distributed under the terms of the Creative Commons Attribution License (https://creativecommons.org/licenses/by/4.0/), which permits unrestricted use, distribution, and reproduction in any medium, provided the original author and source are credited. 


\section{Background of literature}

Innovation is mostly triggered by the need of creating new products or services with new technologies (Garcia \& Calantone, 2002). Unlike inventions, innovations offer an economic value, i.e. innovations are implemented projects rather than bright ideas. Innovation can be differentiated in terms of its degree; there are incremental, radical or disruptive innovations. Incremental innovations represent a low degree of new knowledge, which are mainly reflected in small improvements, compared to radical innovations that involve a high degree of the latest knowledge towards a totally new solution (Dewar \& Dutton, 1986) or a new value proposition (Christensen, 2013). Disruptive innovations have such a high impact that older propositions become outdated. Consequently, innovation is not necessarily around a bold idea and can be achieved in various levels.

The air transportation industry uses innovation not only to achieve cost effective strategies (Janić, 1999). The development is driven by innovation utilizing advanced business models, customer segmentation and new technologies (Franke, 2007). The competition among airports is a common driver of innovation (Huang \& Kaewmee, 2011) that airports made innovation part of their business strategies recently (Ucler \& Martin-Domingo, 2015).

Airports can benefit from innovation initiatives in the design, construction, operation and in passengers' experience processes. For example, one common area of innovation at airports is the use of information and communication technologies (ICT) for interaction that aim to offer efficient, fast and high quality services to customers (Straker \& Wrigley, 2018). Some ICT examples are selfservice technologies at check-in kiosks (Chang \& Yang, 2008), automated board control technologies (Oostveen et al., 2014), radio-frequency identification (RFID)-based baggage tracking systems (Zhang et al., 2008), and mobile applications (Martin-Domingo \& Martín, 2016). There, self-service technologies (SST) allow customers to interact with self-service software (Chen et al., 2015) without any employee involvement (Castillo-Manzano \& LópezValpuesta, 2013). By using these technologies, customers can book a flight, pay for tickets and get flight updates via mobile devices (Lin \& Hsieh, 2011) and companies can reduce labor cost, and increase both service efficiency (Lin \& Hsieh, 2007) and time-efficiency (Chang \& Yang, 2008).

Advanced technologies also enable people to do multiple tasks on their mobile devices while travelling (Harrison et al., 2013). More efficient mobile devices (Radaha \& Johnson, 2013) have resulted in a higher usage of mobile applications and websites at airports. Such applications are simply the easiest and fastest way to provide information to air travelers, and they enable transactions and collaboration. For example, DORA is an application for door to door information of airlines, airports and landside interlines enhancing passenger experience (Baumgartner et al., 2016). Airport applications are often used to generate ancillary revenue from different activities, as for example lounges, car parking and food \& beverage (Halpern \&
Graham, 2013). In addition to new revenue sources, these mobile applications contribute to make airport processes more customer-friendly (Price et al., 2014).

There are many benefits of innovation at airports. For example, Niine et al. (2017) categorizes related outcomes into four main groups as the effect on service price, service quality, service volume and the potential to differentiate; Straker and Wrigley (2018) state that technology usage at airports increases passenger satisfaction; and Lin (2015) confirms innovations can deliver a unique airport's brand experience, which contributes its competitive advantage (Arif et al., 2013). As a result, airports clearly need to practice innovation, however there is no existing work in the literature consolidating airport innovation research as it is spread in various papers and there is no structured overview of innovation possibilities that airports can built their strategy on. Consequently, this paper aims to fulfill the research gap by summarizing and categorizing the airport innovation with usable findings for both the research community and the airport industry.

\section{Methodology}

This paper applies systematic literature review, which investigates existing studies on a certain topic to evaluate and analyze these studies, combining contributions and reaching results about what is and is not known (Denyer \& Tranfield, 2009). The literature review on airport innovation is made by using journal articles, books and conference papers from the Elsevier's Scopus database, because it includes but it is not limited to major aviation-focused journals like Journal of Air Transportation Management and Airport Management (SCImago); and major transportation journals like Transportation Research-Part D, Transport and Environment and Journal of Transportation Engineering.

It is worth to mention that qualitative research in such systematic reviews has been noted as methodological innovation itself (Dixon-Woods, 2010). The basic steps of the qualitative study here were accessing raw data, structuring and categorizing it to further analyze, conclude and interpret as stated by Schilling (2006). First, purposeful sampling (Palinkas et al., 2015) was used for in-depth study due to the rich seam of information (Patton, 2002). Publications were collected using the search criteria "innovation" and "airport" in the title, abstract or keywords sections, i.e. only manuscripts including both words "airport" and "innovation" in any of the indicated sections were selected. Only publications in English between 2000 and 2019 were included in the review. The technologies of the new millennium have facilitated many innovations and Bogicevic et al. (2017) recons that airports only began recently to invest on in technological innovations. In addition, only 55 documents were published during the 31 years' period between $1968-1999$. Therefore, it can be concluded that the 20 years considered can be appropriate for future projections and technology road mapping attempts. 
Purposeful sampling was carried out in three stages, after the used keywords delivered a total of 423 documents: First, 28 conference reviews and 8 short surveys were excluded, because of not being a complete academic resource. In the second step, Nvivo 10 was used due to its ability to import bibliographic references (Azeem et al., 2012). Although there are different computer-assisted software programs for conducting qualitative data analysis (Patton, 2002), Nvivo 10 was used because it has a userfriendly interface for organizing, categorizing and analyzing data (Castleberry, 2014) and delivers an effective coding environment with nodes, making it compatible with thematic analysis approaches (Zamawe, 2015). Since the program is not perfect limitations on data interpretation as described by Dollah et al. (2017) have been taken into consideration, and the control remained with the authors along all processes. The software was used to identify the word frequency of "airport" in the text. Consequently, 15 documents were eliminated with a frequency lower than $0.01 \%$, where airports were mainly used just as an example of public places (Pica et al., 2015). Since the sample size is small and only short texts, i.e. abstracts, were scanned, validity and reliability tests were done manually. Then, in the third step, title, abstract and keywords of remaining documents were read by the authors and those in which innovations directly affect the management of the airports and its operations were selected that 179 documents were excluded focusing on air traffic management, new types of innovative aircrafts, unmanned aerial vehicles, aviation fuel consumption and countries' economy. So that, 193 documents were considered for further analysis in this study.

In order to analyze relevant data in groups, an Excel Spreadsheet was used. First, a descriptive analysis of the data was performed with airport innovation papers classifying by journal name, year of publication and place of origin. Then, content analysis was conducted to distinguish types of innovations at airports. The topics covered in the papers were subsequently organized with the affinity diagram technique (Hanington \& Martin, 2012), where papers were grouped based on their similarity of application. This was made by using cards with short descriptions, tentatively used by a group of experts to form idea clusters. This group of experts were either working in the industry or in academia specifically focusing on innova- tion and aviation, who did select the most general titles for categories and assigned the literature under these categories. As a result, a total of four innovation areas were identified and tabulated: Airport Design, Performance Measurement, ICT and General. In addition to this, approach and degree of the innovation were identified for each paper. While the approach of innovation was adapted from OECD (2018), it was evident during the research that there were no marketing and organization innovation examples. Consequently, the outcomes were easier to be clustered under (i) object innovation that defines innovative changes in products and services, and (ii) subject innovation that defines improvement in processes, which was also particularly in line with the older Oslo Manual definitions. The degree definitions for innovation were adapted from studies of Ettlie et al. (1984) and Augsdörfer et al. (2013).

\section{Findings}

\subsection{Descriptive analysis}

First of all, the geographical spread of the innovation studies was looked at to quantify differences between geographic regions. This coverage is given in Figure 1, which is based on the total of 193 papers subject to this study. Papers without a specific location were designated as worldwide (43\%). Then, it was determined that the majority of the specific studies were addressing airport innovation in Europe (27\%). This was assumed to be a result of the European Union's (EU) transformation policy towards an innovation nation, driven by grants in the Horizon 2020 Framework Programme for Research and Innovation (H2020) with calls regarding societal challenges, smart, green and integrated transportation, and further supported by academic projects such as Clean Sky, DORA, SESARJU. These initiatives in the EU could partially explain the greater amount of academic research on airport innovation than in other parts of the world.

Then, the annual change of the innovation research was investigated by a frequency chart to quantify the expected increase over the years as mentioned by Fagerberg and Verspagen (2009). On the one hand, it was observed that most papers were published in recent years that it is safe to say that there is an increasing interest in innovation

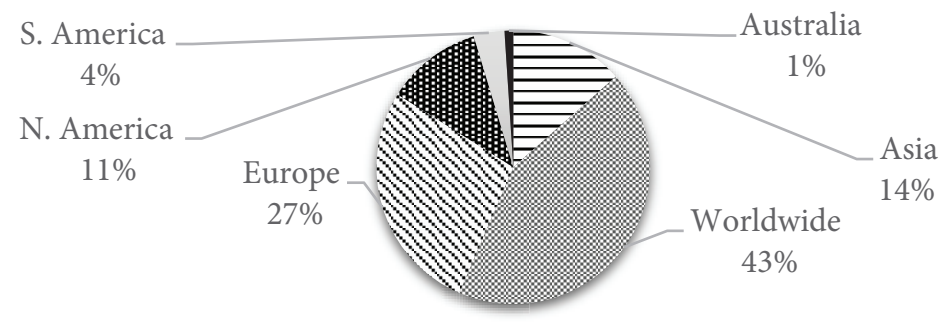

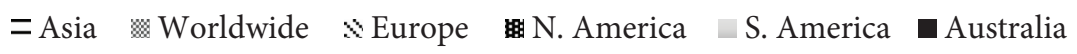

Figure 1. Geographical coverage of airport innovation literature 
at airports. On the other hand, the research was not continuous: in 2010 there were no publications on airport innovation and the average of 2009-2012 has by far a lover mean frequency than 2008 and 2013. One can say that the method of this study narrowing down to the papers with the search words "airport" and "innovation" in specific section of papers might be the reason. However, this ontology context is also existing in other years that it is an interesting fact, which could be explained with related calls of support programs. Under the bottom line, the predominance of relevant papers appeared within the last seven years as shown in Figure 2.

Moreover, there were 157 different journals, where the 193 selected papers appeared in accordance with the search criteria. During the search, there was neither a preferred field such as aviation, nor a restriction based on the field of the journals. However, Journal of Airport Management, Journal of Air Transport Management and Jane's Airport Review were the most common sources with the highest number of published papers, 7, 5 and 4 respectively. So, the majority of the research was done by aviation scholars in aviation related journals. Furthermore, the number of studies of each author on this subject was counted manually and there was a smooth distribution of papers across authors, i.e. authors have written 1 or maximum 2 papers about airport innovation, which indicates that there is a gap in the literature for scholars concentrating solely on airport innovation research.

\subsection{Content analysis}

Content analysis is a systematic way (Mayring, 2004) to study repeating patterns in various formats such as text, video or other communication means. It is widely used in qualitative research allowing researchers categorizing words into less content-related categories (Elo \& Kyngäs, 2008). Here it was also used categorization. Consequently, the papers were divided into 4 groups in terms of the topic they cover, namely General (53\%), Airport Design (19\%), ICT (15\%) and Performance Measurement (13\%). The distribution of these 4 areas in airport innovation was then examined within 193 papers with respect to frequency and coverage which are explained next.

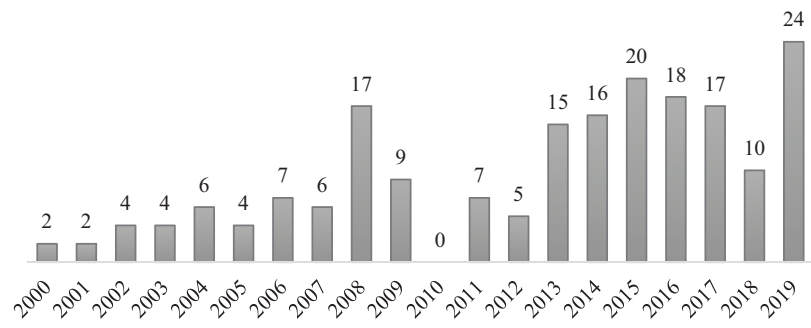

Figure 2. Publication years of the studies on airport innovation literature

\subsubsection{The general objectives on airport innovation}

102 papers did mention airport innovation generally without any specific focus, or the focus area was singular that there was no possibility to assign a category for that. Thus, there are papers in the general objectives category, which examined airport innovation from many different perspectives. Such innovations can be found in different parts of the airport and examples of different were classified in this category with respect to the associated approach and degree for innovation (see Figure 3).

The most frequently mentioned innovation related general topic was security. Some specific technologies were also in security related papers, but innovations were only facilitating but not focusing on ICT. Consequently, such security papers were included in the general objectives section and there was no separate category created for security. As an example, Thomas et al. (2016) states about facial recognition software used at airports as well as Jupe and Keatley (2019) mention how artificial intelligence can be used for coping with security issues at airports, and Möller et al. (2018) talk about intelligent system application with the Internet of Things. Then, some studies like Wong et al. (2006) and Boussadia (2009) addressed the historical development of security technologies used at the airport, where privatization was one of the major driving forces (Bowyer \& Chapman, 2014; Sinha \& Jha, 2019). Risk analysis was another aspect of security mentioned by Kyriazanos et al. (2016) and Filipoui et al. (2012).

Likewise, there was a significant focus on the passenger experience (Pat-El \& Orshan, 2015; Elliott \& Radford, 2015; Melníkova et al., 2018; Hinterholzer \& GarsiaAlonso, 2018; Mayer, 2019). Then, numerous studies have examined the effects of airport on administrative issues such as R\&D projects (Brooker, 2009), process management (Gubenko \& Ksenofontova, 2015) and pricing strategies (Basso \& Zhang, 2006). Marketing concerns such as service and brand loyalty (de Oliveira \& Caetano, 2019), passenger loyalty (Akamavi et al., 2015), customer satisfaction (Arif et al., 2013; Lin, 2015) were investigated.

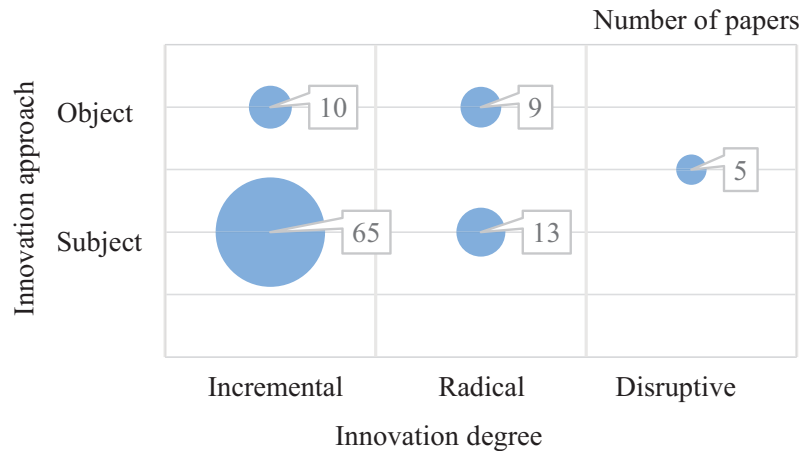

Figure 3. The associated approach and degree for innovation of general objectives category 


\subsubsection{Design}

Airport design itself is a difficult and complex process, which includes several stages such as planning and constructing (De Neufville \& Odoni, 2003). The importance of innovations on airport design was found to be considerable as innovative facilities provide smooth service processes both for service providers and passengers with a great impact on efficiency (Medvedev et al., 2017). Consequently, the most frequently mentioned field of innovation after the general case was design studies with a total of 36 of papers (see Figure 4). Although there was small attention to subject innovation in this category, the object innovation was discussed in depth for the land- and the airside. In terms of airside, innovation was found to be implemented on runways (Herrema, 2014), taxiways (Crawford, 2008; Schmidt et al., 2012), navigation systems (Mayer et al., 2015) and airfield pavements (Hachiya et al., 2005; Dawson et al., 2008; Lazar \& Emery, 2013). For the landside, innovation was part of the construction (Harty, 2005; Guangshe et al., 2008) and terminal facilities (Davies et al., 2009; Gil et al., 2012). So, innovations for developing aeronautical as well non-aeronautical revenues were included.

\subsubsection{Information Communication Technologies (ICT)}

ICT directly affects customers service perceptions (Brida et al., 2016). It can be used at airports for self-service machines or security equipment (Chen et al., 2015), impacting on the experience and thus customer satisfaction (Chen \& Wu, 2014; Yu \& Huang, 2014; Chen et al., 2015). Consequently, it has been subject of academic studies that there were 30 publications within this category corresponding to $15 \%$ (see Figure 5). Furthermore, many other papers such as security do also leverage ICT as stated above that the coverage is even larger.

When all of these studies are examined, it is possible to observe a trend over years: While the focus in early 2000 s was on "people mover systems" (Sproule, 2001, 2009), the focus shift latter towards mobile applications (Kohno \& Fujii, 2011; Fei et al., 2016), RFID systems (Khan, 2011;

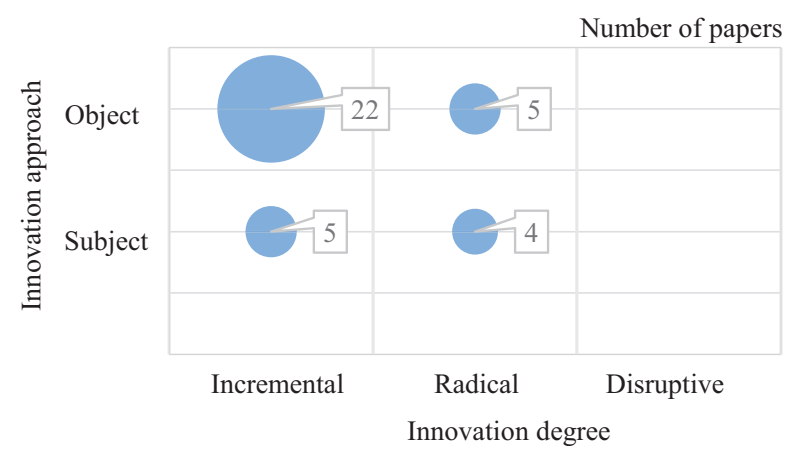

Figure 4. The associated approach and degree for innovation of design category

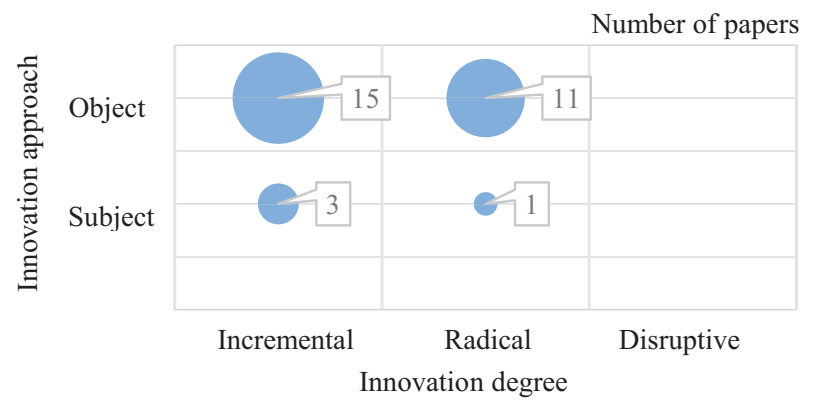

Figure 5. The associated approach and degree for innovation of ICT category

Mirza \& Brohi, 2013), SST's (Kim et al., 2017; Bruno et al., 2019) and biometric systems (Kim et al., 2019; Negri et al., 2019). People mover systems are still being used at airports (Kapala, 2009), but they became industry standard over time that they are not classified as an innovation anymore. Therefore, it is possible to say that people mover system is one of the oldest technology used at airports (Sproule, 2009). Nevertheless, new ICT technologies are more recent, and in particular self-service technologies, which are becoming the "new standard" at airports allowing passengers different choices based on their preference (Ueda \& Kurahashi, 2016). These technologies are used at different passenger processes like check-in (Bruno et al., 2019); biometric control systems, facial recognition systems and automated border control systems (Oostveen et al., 2014; Duman, 2019; Kim et al., 2019; Negri et al., 2019); and baggage handling (Kim et al., 2017). The acceptance of such technologies were one of the main concerns of the research papers in this category and their impact on passenger's experience was researched (Chen et al., 2015; Fei et al., 2016).

\subsubsection{Performance measurement}

From the operations research perspective, the performance and profitability are key. Thus, efficiency is an important key indicator, which is used as a guide in strategic planning and competitive analysis of airports (Bazargan \& Vasigh, 2003). Performance measurement is not an easy task because airports are large complex business environments consisting of different processes distributed across distinct companies, which is further complicated by regulatory issues (Graham, 2013). However, this challenge is also the driving force for innovation (Pitt \& Tucker, 2008). Consequently, innovation in performance measurement was found to be a critical research area concerning airport economics and management (Fasone \& Zapata-Aguirre, 2016) and 25 publications were classified under the category for airport performance (see Figure 6).

When airport performance is looked at in depth, there are two main vertices, which are managerial and operational performance. In line with this distinction, research was evident in effective wayfinding in terminal building (Ardi et al., 2019), digital technologies that are used in airport ground operations (Kovynyov \& Mikut, 2019), taxi 


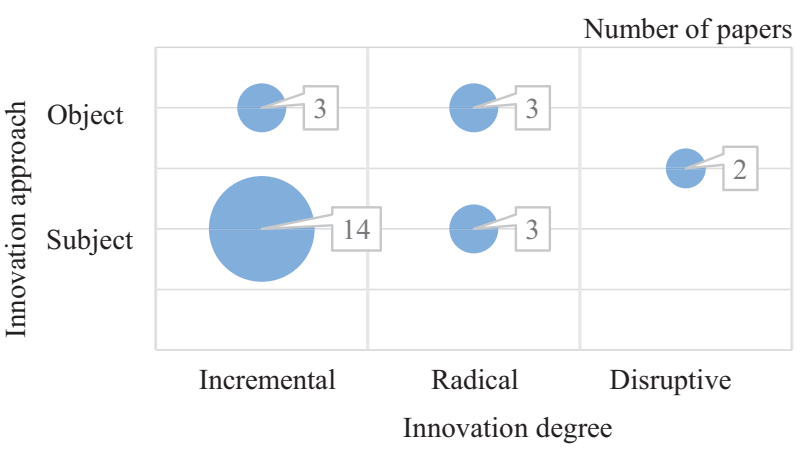

Figure 6. The associated approach and degree for innovation of performance measurement category

systems affecting ground operation and gate congestion (Soepnel \& Roling, 2017), and evaluation of performance of asphalt types (White, 2017). Then, in managerial perspective of the airport performance, studies gave attention to capacity management (Aulman, 2018), efficiency concerns (Neto et al., 2019) and business performance (Fasone \& Zapata-Aguirre, 2016).

\section{Discussion}

As Cooper (2011) states, a good mix of different innovation typologies is required in organizations to maximize success. This varies from simple improvements towards bold innovations with a disruption potential. This can be achieved either by new products and services, or by new processes. Organizational innovation can be challenging for airports due to a tight regulation. Then, despite airports having a tremendous marketing innovation potential it was not evident in the literature. Therefore, further categorization for the innovation approach was based on subject and object innovation (Taran et al., 2015), which is also in line with the former OECD (2005) definitions. Subject innovation was mentioned recently more than object innovation, where it was more common in papers classified in general objectives (Figure 7). This shift from object to subject innovation might support the new focal point of experience (Chao \& Kavadias, 2008) and co-creation, but it can also simply be due to the lack of research

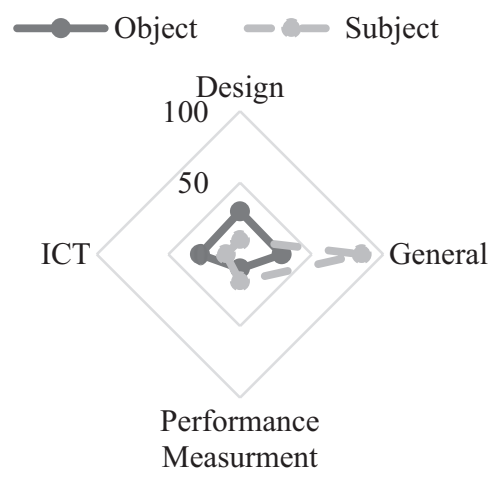

Figure 7. Innovation approach by category related to object innovation at airports. Whatever the reason might be, there is a gap which can be best filled with game-changing bold innovation. Consequently, strategic planning for airports must involve bold innovation targets filling up all the "strategic buckets" (Chao \& Kavadias, 2008) including subject as well object innovation for different strategies.

Furthermore, the degree of innovation was categorized according to OECD (2005) as (i) incremental innovation when there is a continuous improvement in product and services (Bhaskaran, 2006), (ii) radical innovation when there is crucial change in input to output processes (Hage, 1980) and (iii) disruptive innovation, described as a game changer, which brings new value proposition to products and services (Christensen, 2013). Consequently, Figure 8 shows the summary of the analyzed research subject to the degree of innovation. Incremental innovation was the most common subcategory under study with 134 papers $(70 \%)$. It was also found that incremental innovation had the largest coverage with 80 papers in general objectives. Consequently, the majority of the work is focusing on enhancements of daily routines. Then, there were 49 papers (25\%) for radical innovation. Finally, there were only 7 studies addressing disruptive innovation at airports, where design and ICT were not covered at all. Moreover, there were studies not investigating solely disruptive innovation, but looking at it in conjunction with the other categories, which covered $5 \%$ of papers. This was no surprise, because disruptive innovations require a vast amount of changes and all of these changes occur with different dimensions over time, which progress at airports is expected to be very slow due to the legislations and the nature of the processes.

Lastly, the revenue sources of airports were analyzed and classified as (i) aeronautical revenue, (ii) commercial revenue and (iii) indirect value. Considering that aeronautical revenues are revenues generated from airlines' operation activities (Battal \& Bakir, 2017), they include landing fees, passenger service charges, aircraft parking and hangar fees, and ground service charges. Consequently, non-aeronautical revenues or commercial revenues are explained as revenues generated from activities

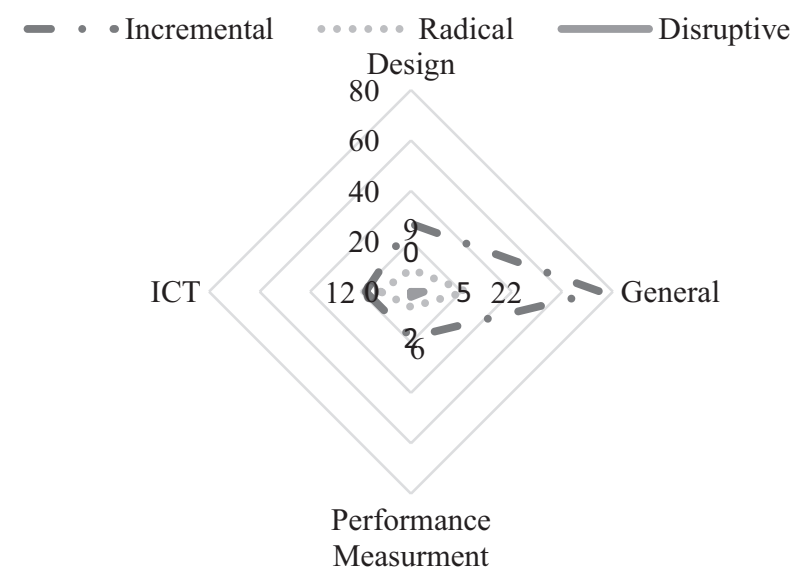

Figure 8. Innovation degree by category 
not directly related to airline operation activities (Doganis, 1992). The third subcategory, the indirect value of innovation, represents gains which cannot be reckoned with traditional accounting (Grant et al., 2013), which impact cannot be detected easily, especially in the short term. Indirect value for airports includes impacts over time either due to system enhancements reflected in air traveler satisfaction, or it is built in the ecosystem/supply chain. Consequently, this subcategory also includes impacts on the related local economy.

There, the performance measurement and design focused more on the revenue side of the business, but the research on airport innovation was found to be more concentrated on indirect values. Indeed, ICT and general categories addressed indirect value in long term. Consequently, there is an ambiguity in value creation with respect to the definition of innovation. Innovation is about quantifiable value and ought to include measurable outputs via products or services. However, the literature tends to lack such connections and instead the indirect value is a major focal point. Nevertheless, indirect value is mostly within subject innovation and, which can only be useful when considered together with new products or services, i.e. the object side is less focused on at airports. This might also be a result of grants in the H2020 program, trackable to the societal challenges and transformation efforts of the $\mathrm{EU}$, but the end effect remains the same. Consequently, scholars and airport professionals have to focus more on new products and services along marketing innovation, which has not been researched.

Specific examples suggest that the focal area of airport innovation can be further quantified. For incremental innovation, there is a focus on ICT value (Smith \& Ugolini, 2017), infrastructure enhancement (Lorenzo et al., 2004), and usage of electrical vehicles (Silvester et al., 2013). In addition, there are different optimization projects such as optimization of terminal to reduce environmental impact (Lister, 2008), runway optimization (Herrema, 2014) and reengineering in cargo handling processes by business process modelling and automation technologies (Gubenko \& Ksenofontova, 2015). This is underlining the traditional nature of airports, i.e. consolidated large organizations focusing on the enhancements rather than the change itself.

Furthermore, there are enhancements in design, training, border control, self-service technologies such as check-in and baggage handling, radio frequency identification (RFID), security (Gil et al., 2012; Chen et al., 2015; Negri et al., 2019), and sustainability telepresence systems in order to reduce time for drop-off/ pick-up and improve transportation (Ryley et al., 2013), which can be categorized as both incremental and partially radical innovations. Aside from these, the interconnection of the duty free chain in distinct locations (Ucler \& Martin-Domingo, 2015), and smart airport design (Elliott \& Radford, 2015) are examples of radical innovation utilizing ICT improvements. As stated before, these studies did not deal with disruptive innovation solely.
Prior to the research, technological push aspects such as technology transfer from robotics, Industry 4.0 and augmented reality (AR) were expected to be significantly present in the airport innovation research. Similarly, new modes of transportation like hyper loop, or new aircraft types such as spacecraft, new very large aircraft or small vertical take-off and landing (VTOL) aircraft were not covered in the innovation literature for airports. Thus technology push did not play a major role there. Instead, marketing pull with respect to innovation at airports was the major concern of researchers and airport professionals funding the research. This might also be interpreted as indicating that airport professionals work in a reactive manner, excluding strategical innovation efforts in their usual agenda or that they prefer to address such information internally. This can also perhaps be interpreted as a consequence of the limited competition environment in the airport sector. Whatever the reason might be, there is room for improvement especially by technology road mapping and technology scouting.

Then, there was no direct evidence of new product or new service innovations at airports, i.e. the literature did not include new offerings at airports. Even if it would seem that there should be such papers, since they are not interrelated with airports specifically, they were not found with the present keywords. A further interesting point is that technology-focused papers are not reporting on innovation, i.e. are not concerned with the conversion to commercial products or services, or don't address value in the processes. This underlines the lack of collaborative product/ service development among researchers and airport professionals. Thus, airport management could adopt innovation management practices as in other sectors and drive the research proactively. This is also emphasized by the fact that almost half of the reviewed papers mentioned innovation without any reference to a specific product/ service or process.

\section{Conclusions and future research}

A literature review was conducted on innovation at airports to examine the airport-innovation research framework. There, the areas of interest and types of innovation were structured with respect to journal name, innovation type, degree of innovation and its origin. The main aim was to identify the main focus of studies on airport innovation and to categorize these studies accordingly. This indicated trends and gaps in the literature, thus this study provides a guide in airport innovation for practitioners as well for future studies. Since there was no previous review on this search criteria, it is intended to expand the existing literature. Practitioners can use this study to create or enhance their innovation strategies.

It was found that the majority of the research originated from Europe. Majority of the papers were published recently, indicating a rising trend in innovation at airports. The search was made across all journals, but 
mainly publications in aviation related journals were concerned with innovation at airports. Moreover, most of the researchers published only a limited number of innovation papers. This indicates that innovation generalists have to work closer with aviation professionals. Here a clear research gap can be seen for airport innovation. This could be covered by innovation scholars entering in the airport field, aviation scholars studying airport innovations or even a multidisciplinary research team with experience of innovation and airport management.

Usually, general innovation literature has a balanced distribution across product/service-, process-, marketing- and organizational innovation. However, when looking at airport innovation, majority of the literature addressed subject innovation compared to object innovation. The research of new products, new services and market innovation was not well covered in the literature. Therefore, they can be clearly areas to be analyzed and improved in the future.

Then, based on the research findings, the airport industry seems to utilize technologies from other industries, which are leveraged into optimization of existing processes. On the one hand this is a strength, since it indicates technology transfer, but on the other hand it might be a weakness, since it might imply that there is no cooperation with external stakeholders to reengineer processes. Thus, airports should engage in strategic thinking beside daily proactive operations that reengineering and bold innovation should be driven by the technology and the market. This can assure that airports utilize systematic innovation that ad-hoc efforts become daily routine.

Some object innovation examples were found, where new services based on ICT were offered such as self-service technologies, navigations services or mobile applications. This might be understood that new product/service development is given a high priority by airports, but many of these cases were simply subject innovation cases implementing ICT in existing or enhanced processes. So, on the one hand totally new products/services are missing, but on the other hand the ICT is leveraged for customer experience, which is positive. The experience economy is present in aviation, and innovative airports tend to cocreate value with the passengers in an open context with open structured facilities, i.e. they try to reduce boundaries and form products/services in collaboration with the passenger. Together with the digital connectivity, this can deliver the inclusion of the passenger in the process. The passenger, in addition to being a consumer, is then upgraded in innovative airports to a content provider. This is an important transformation and airports would be advised to take advantage of it.

Then a content analysis was made to cluster the papers, resulting in the categorization of innovations at airports into general Objectives, Design, ICT and Performance Measurement. 53\% of the work was classified in subcategories as general innovation, while design innovation was second with $19 \%$ followed by ICT and performance measurement with $15 \%$ and $13 \%$ respectively. It was seen that security was a significant innovation area across all these subcategories.

Independent of the place of origin or the subcategory, incremental innovation was found to be more frequent. Considering that many leading companies might lose their position when not managing disruptive technologies adequately, this can become a threat for many airports. Again, apart from the usual business practice of focusing on market pull, forthcoming game-changers in the form of market changes and disruptive new technologies should be looked at and included in strategy. This requires proactive airport professionals, who collaborate more with researchers from distinct sectors for product/service development. To exemplify, those major developments in transportation modes can be looked at in the future. This might include alternative or complementary technologies such as Hyperloop, new aircraft types and other new technologies from Industry 4.0, which may change the constitution and the infrastructure of airports. Moreover, the potential impact of robotic technologies and cyber-physical interfaces can be looked into further to conceptualize new approaches. This involves technology scouting, which was not covered within this work but might be an avenue for future research.

Finally, this study attempts to explain which innovation approach and category was addressed by previous studies. So, it is aimed to indicate research trends by emphasizing different information such as publication years of studies and geographical regions. The literature assessment was made by the keywords innovation and airport applied in the papers in Elsevier's Scopus database. Since this was made in English Language and it was only utilizing the title, abstract and keywords of the papers there might be limitations in this context. Since the literature review did not cover innovation efforts of airports disseminated by conferences or industrial magazines, there is a restriction, which is described in the method section as well. Then, there can be also unreported innovation efforts of airports. This could be an area for future research, utilizing reviews with a new set of keywords or search criteria and new samples. However, having a high number of papers it is assumed that the statistical significance and the validity are given.

\section{References}

Akamavi, R. K., Mohamed, E., Pellmann, K. \& Xu, Y. (2015). Key determinants of passenger loyalty in the low-cost airline business. Tourism Management, 46, 528-545. https://doi.org/10.1016/j.tourman.2014.07.010

Amit, R., \& Zott, C. (2012). Creating value through business model innovation. MIT Sloan Management Review, 53(3). http://aproaingenieria.com/intranet/uploads/creating-valuethrough-business-model-innovation.pdf

Ardi, R., Fikri, S., \& Rahayu, P. D. (2019, September). Investigating effectiveness wayfinding on terminal navigation in terminal 2 Soekarno-Hatta Airport. In Proceedings of the $5^{\text {th }}$ International Conference on Industrial and Business Engineering (pp. 212217). ICIBE. https://doi.org/10.1145/3364335.3364340 
Arif, M., Gupta, A., \& Williams, A. (2013). Customer service in the aviation industry - An exploratory analysis of UAE airports. Journal of Air Transport Management, 32, 1-7. https://doi.org/10.1016/j.jairtraman.2013.05.001

Augsdörfer, P., Möslein, K., \& Richter, A. (2013). Radical, discontinuous and disruptive innovation - what's the difference. Series on Technology Management: Vol. 22. Discontinuous innovation: Learning to manage the unexpected (pp. 9-39). Imperial College Press.

https://doi.org/10.1142/9781848167810_0002

Aulman, J. (2018). Meeting airport capacity demand using new technologies and innovations. Journal of Airport Management, 13(1), 57-63.

Azeem, M., Salfi, N. A., \& Dogar, A. H. (2012). Usage of NVivo software for qualitative data analysis. Academic Research International, 2(1), 262-266.

Bazargan, M., \& Vasigh, B. (2003). Size versus efficiency: a case study of US commercial airports. Journal of Air Transport Management, 9(3), 187-193.

https://doi.org/10.1016/S0969-6997(02)00084-4

Basso, L., \& Zhang, A. (2006). Peak-Load pricing in a vertical setting: the case of airports and airlines. AgEcon, No. 14272016-118562.

Battal, U., \& Bakır, M. (2017). The current situation and change in airport revenues: research on The Europe's five busiest airports. International Journal of Academic Research in Business and Social Sciences, 7(7), 287-303.

https://doi.org/10.6007/IJARBSS/v7-i7/3096

Baumgartner, C., Kätker, J., \& Tura, N. (2016). DORA - integration of air transport in overall urban and regional mobility information. Transportation Research Procedia, 14, 3238-3246. https://doi.org/10.1016/j.trpro.2016.05.268

Bhaskaran, S. (2006). Incremental innovation and business performance: Small and medium-size food enterprises in a concentrated industry environment. Journal of Small Business Management, 44(1), 64-80.

https://doi.org/10.1111/j.1540-627X.2006.00154.X

Bogicevic, V., Bujisic, M., Bilgihan, A., Yang, W., \& Cobanoglu, C. (2017). The impact of traveler-focused airport technology on traveler satisfaction. Technological Forecasting and Social Change, 123, 351-361.

https://doi.org/10.1016/j.techfore.2017.03.038

Boussadia, K. (2009). The evolution of airport screening technology. Biometric Technology Today, 17(2), 7-8.

https://doi.org/10.1016/S0969-4765(09)70056-6

Bowyer, D., \& Chapman, R. L. (2014). Does privatisation drive innovation? Business model innovation through stakeholder viewpoints: the case of Sydney Airport 10 years post-privatisation. Journal of Management \& Organization, 20(3), 365386. https://doi.org/10.1017/jmo.2014.16

Brida, J. G., Moreno-Izquierdo, L., \& Zapata-Aguirre, S. (2016). Customer perception of service quality: The role of Information and Communication Technologies (ICTs) at airport functional areas. Tourism Management Perspectives, 20, 209216. https://doi.org/10.1016/j.tmp.2016.09.003

Brooker, P. (2009). SESAR: R\&D and Project Portfolios for airline business needs. Journal of Navigation, 62(2), 203-237. https://doi.org/10.1017/S0373463308005237

Bruno, G., Diglio, A., Genovese, A., \& Piccolo, C. (2019). A decision support system to improve performances of airport check-in services. Soft Computing, 23(4), 2877-2886. https://doi.org/10.1007/s00500-018-3301-z

Castillo-Manzano, J. I., \& López-Valpuesta, L. (2013). Check-in services and passenger behaviour: Self service technologies in airport systems. Computers in Human Behavior, 29(6), 2431-2437. https://doi.org/10.1016/j.chb.2013.05.030

Castleberry, A. (2014). NVivo 10 [software program]. Version 10. QSR International; 2012. American Journal of Pharmaceutical Education, 78(1). https://doi.org/10.5688/ajpe78125

Chambers, R. D. (2007). Tackling uncertainty in airport design: A real options approach [Doctoral dissertation, Massachusetts Institute of Technology, Engineering Systems Division, Technology and Policy Program].

Chang, H. L., \& Yang, C. H. (2008). Do airline self-service checkin kiosks meet the needs of passengers? Tourism Management, 29(5), 980-993. https://doi.org/10.1016/j.tourman.2007.12.002

Chao, R. O., \& Kavadias, S. (2008). A theoretical framework for managing the new product development portfolio: When and how to use strategic buckets. Management Science, 54(5), 907-921. https://doi.org/10.1287/mnsc.1070.0828

Chen, J. K. C., Batchuluun, A., \& Batnasan, J. (2015). Services innovation impact to customer satisfaction and customer value enhancement in airport. Technology in Society, 43, 219-230. https://doi.org/10.1016/j.techsoc.2015.05.010

Chen, L. S. L., \& Wu, K. I. F. (2014). Antecedents of intention to use CUSS system: moderating effects of self-efficacy. Service Business, 8(4), 615-634.

https://doi.org/10.1007/s11628-013-0210-1

Christensen, C. (2013). The innovator's dilemma: when new technologies cause great firms to fail. Harvard Business Review Press.

Cooper, R. G. (2011). Perspective: The innovation dilemma: how to innovate when the market is mature. Journal of Product Innovation Management, 28(s1), 2-27.

https://doi.org/10.1111/j.1540-5885.2011.00858.x

Crawford, K. (2008). Construction of a 5000 meter concrete runway in southern California. In Annual Conference - Canadian Society for Civil Engineering, 1, 169-178. Quebec City, Quebec, Canada.

Davies, A., Gann, D., \& Douglas, T. (2009). Innovation in megaprojects: systems integration at London Heathrow Terminal 5. California Management Review, 51(2), 101-125. https://doi.org/10.2307/41166482

Dawson, T., Lingham, K., Yenn, R., Beveridge, J., Moore, R., \& Prentice, M. (2008, May). Heathrow Terminal 5: building substructures and pavements. In Proceedings of the Institution of Civil Engineers-Civil Engineering, 161(5), 38-44. Thomas Telford Ltd. https://doi.org/10.1680/cien.2007.161.5.38

de Oliveira, D. S., \& Caetano, M. (2019). Market strategy development and innovation to strengthen consumer-based equity: The case of Brazilian airlines. Journal of Air Transport Management, 75, 103-110.

https://doi.org/10.1016/j.jairtraman.2018.12.006

Denyer, D., \& Tranfield, D. (2009). Producing a systematic review. In D. A. Buchanan \& A. Bryman (Eds.), The Sage handbook of organizational research methods (pp. 671-689). Sage Publications Ltd.

Dewar, R. D., \& Dutton, J. E. (1986). The adoption of radical and incremental innovations: an empirical analysis. Management Science, 32(11). https://doi.org/10.1287/mnsc.32.11.1422

De Neufville, R., \& Odoni, A. (2003). Airport systems: Planning, design and management ( $2^{\text {nd }}$ ed.). McGraw-Hill.

Dixon-Woods, M. (2010). Systematic reviews and qualitative methods. In Qualitative research: theory, method and practice (3rd ed., pp. 331-346). Sage.

Doganis, R. (1992). The airport business. Routledge.

Dollah, S., Abduh, A., \& Rosmaladewi, M. (2017, September). Benefits and drawbacks of NVivo QSR application. In Advances 
in Social Science, Education, Science, and Technology (ICEST 2017), Vol. 149. The 2nd International Conference on Education, Science, and Technology (ICEST 2017). Atlantis Press. https://doi.org/10.2991/icest-17.2017.21

Duman, T. (2019). Innovation in a zero-risk environment: Facial recognition experiment at Helsinki Airport. Journal of Airport Management, 13(3), 215-224.

Elliott, A., \& Radford, D. (2015). Terminal experimentation: the transformation of experiences, events and escapes at global airports. Environment and Planning D: Society and Space, 33(6), 1063-1079. https://doi.org/10.1177/0263775815595407

Elo, S., \& Kyngäs, H. (2008). The qualitative content analysis process. Journal of Advanced Nursing, 62(1), 107-115. https://doi.org/10.1111/j.1365-2648.2007.04569.x

Ettlie, J. E., Bridges, W. P., \& O’keefe, R. D. (1984). Organization strategy and structural differences for radical versus incremental innovation. Management Science, 30(6), 682-695. https://doi.org/10.1287/mnsc.30.6.682

Fagerberg, J., \& Verspagen, B. (2009). Innovation studies - The emerging structure of a new scientific field. Research Policy, 38(2), 218-233. https://doi.org/10.1016/j.respol.2008.12.006

Fasone, V., \& Zapata-Aguirre, S. (2016). Measuring business performance in the airport context: a critical review of literature. International Journal of Productivity and Performance Management, 65(8). https://doi.org/10.1108/IJPPM-06-2015-0090

Fei, T., de Joux, N., Kefalidou, G., D’Cruz, M., \& Sharples, S. (2016, September). Towards understanding information needs and user acceptance of mobile technologies to improve passenger experience in airports. In Proceedings of the European Conference on Cognitive Ergonomics, 7 (pp. 1-4). https:// doi.org/10.1145/2970930.2970938

Filipoui, A., Radu, C., \& Berbente, C. (2012). Severity assessment for aeronautical risk analysis. UPB Scientific Bulletin, Series D, $74(4), 61-74$.

Franke, M. (2007). Innovation: The winning formula to regain profitability in aviation? Journal of Air Transport Management, 13(1), 23-30. https://doi.org/10.1016/j.jairtraman.2006.11.003

Garcia, R., \& Calantone, R. (2002). A critical look at technological innovation typology and innovativeness terminology: a literature review. Journal of Product Innovation Management, 19(2), 110-132.

https://doi.org/10.1111/1540-5885.1920110

Gil, N., Miozzo, M., \& Massini, S. (2012). The innovation potential of new infrastructure development: An empirical study of Heathrow airport's T5 project. Research Policy, 41(2), 452466. https://doi.org/10.1016/j.respol.2011.10.011

Graham, A. (2009). How important are commercial revenues to today's airports? Journal of Air Transport Management, 15(3), 106-111. https://doi.org/10.1016/j.jairtraman.2008.11.004

Graham, A. (2013). Managing airports ( $4^{\text {th }}$ ed.). Routledge. https://doi.org/10.4324/9780080473284

Grant, K., Alefantos, T., Meyer, M., \& Edgar, D. (2013). Capturing and measuring technology based service innovation A case analysis within theory and practice. International Journal of Information Management, 33(5), 899-905. https://doi.org/10.1016/j.ijinfomgt.2013.07.002

Guangshe, J., Li, C., Jianguo, C., Shuisen, Z., \& Jin, W. (2008). Application of organizational project management maturity model (OPM3) to construction in China: An empirical study. In 2008 IEEE International Conference on Information Management, Innovation Management and Industrial Engineering, 2, 56-62. https://doi.org/10.1109/ICIII.2008.182
Gubenko, A. V., \& Ksenofontova, T. Y. (2015). Strategy to Increase the state's role in the business process management on the airport service market. Journal of Internet Banking and Commerce, 20(S1).

https://doi.org/10.4172/1204-5357.S1-005

Hachiya, Y., Ito, A., \& Tanaka, H. (2005). Application of Precast RC Slab Pavement at Airports [Conference presentation]. $8^{\text {th }}$ International Conference on Concrete Pavements. Colorado, USA.

Hage, J. (1980). Theories of organizations: Form, process, and transformation. John Wiley \& Sons.

Halpern, N., \& Graham, A. (2013). Airport marketing. Routledge. https://doi.org/10.4324/9780203117903

Hanington, B., \& Martin, B. (2012). Universal methods of design: 100 ways to research complex problems, develop innovative ideas, and design effective solutions. Rockport Publishers.

Harrison, R., Flood, D., \& Duce, D. (2013). Usability of mobile applications: literature review and rationale for a new usability model. Journal of Interaction Science, 1.

https://doi.org/10.1186/2194-0827-1-1

Harty, C. (2005). Innovation in construction: A sociology of technology approach. Building Research \& Information, 33(6), 512-522. https://doi.org/10.1080/09613210500288605

Herrema, F. F. H. (2014). Compression on final approach and Time Based Separation for optimized runway delivery. Delft University of Technology.

Hinterholzer, T., \& Garcia-Alonso, A. (2018). Munich airport's passenger experience management framework: Key success factors. Journal of Airport Management, 12(3), 272-282.

Huang, Y. Y., \& Kaewmee, K. (2011). The impact of service quality and service innovation on technology acceptance model [Conference presentation]. International Conference on Business and Information. Bangkok, Thailand.

Humphrey, J., \& Schmitz, H. (2002). How does insertion in global value chains affect upgrading in industrial clusters? Regional Studies, 36(9), 1017-1027. https://doi.org/10.1080/0034340022000022198

Jacobides, M. G., Knudsen, T., \& Augier, M. (2006). Benefiting from innovation: Value creation, value appropriation and the role of industry architectures. Research Policy, 35(8), 12001221. https://doi.org/10.1016/j.respol.2006.09.005

Janić, M. (1999). Aviation and externalities: The accomplishments and problems. Transportation Research Part D: Transport and Environment, 4(3), 159-180.

https://doi.org/10.1016/S1361-9209(99)00003-6

Jupe, L. M., \& Keatley, D. A. (2019). Airport artificial intelligence can detect deception: Or am I lying? Security Journal, 33, 622-635. https://doi.org/10.1057/s41284-019-00204-7

Kapala, J. (2009). APM Systems: The key to Atlanta airport expansion. In $12^{\text {th }}$ International Conference of Automated People Movers 2009: Connecting People, Connecting Places, Connecting Modes (pp. 69-79). ASCE Library. https://doi.org/10.1061/41038(343)8

Khan, E. A. (2011, November). An RFID-based system for pilgrim management in King Abdul Aziz International Airport. In 2011 International Conference on Information Management, Innovation Management and Industrial Engineering (Vol. 1, pp. 124-129). IEEE. https://doi.org/10.1109/ICIII.2011.36

Kim, C., Costello, F. J., \& Lee, K. C. (2019). Integrating qualitative comparative analysis and support vector machine methods to reduce passengers' resistance to biometric e-gates for sustainable airport operations. Sustainability, 11(19), 5349. https://doi.org/10.3390/su11195349 
Kim, Y. C., Cha, H., \& Kim, T. (2017). Ahkera Smart Tech: A high-tech venture's global entrepreneurship in Asia. Asian Case Research Journal, 21(02), 311-346.

https://doi.org/10.1142/S0218927517500110

Kohno, I., \& Fujii, H. (2011, July). User-centered approach for NEC product development. In International Conference on Human-Computer Interaction (pp. 48-52). Springer. https://doi.org/10.1007/978-3-642-22098-2_10

Kovynyov, I., \& Mikut, R. (2019). Digital technologies in airport ground operations. NETNOMICS: Economic Research and Electronic Networking, 20(1), 1-30.

https://doi.org/10.1007/s11066-019-09132-5

Kyriazanos, D. M., Segou, O. E., Zalonis, A., \& Thomopoulos, S. C. (2016). FlySec: A risk-based airport security management system based on security as a service concept. In Proccedings Volume 9842: Signal Processing, Sensor/Information Fusion, and Target Recognition (SPIE), XXV, 98420CV. https://doi.org/10.1117/12.2224031

Lazar, M., \& Emery, J. (2013). An innovative paver system for aircraft pavements. Advanced Materials Research, 723, 1011-1018. https://doi.org/10.4028/www.scientific.net/AMR.723.1011

Lin, J. S. C., \& Hsieh, P. L. (2007). The influence of technology readiness on satisfaction and behavioral intentions toward self-service technologies. Computers in Human Behavior, 23(3), 1597-1615. https://doi.org/10.1016/j.chb.2005.07.006

Lin, J. S. C., \& Hsieh, P. L. (2011). Assessing the self-service technology encounters: development and validation of SSTQUAL scale. Journal of Retailing, 87(2), 194-206.

https://doi.org/10.1016/j.jretai.2011.02.006

Lin, Y. H. (2015). Innovative brand experience's influence on brand equity and brand satisfaction. Journal of Business Research, 68(11), 2254-2259.

https://doi.org/10.1016/j.jbusres.2015.06.007

Lister, B. (2008, May). Heathrow Terminal 5: enhancing environmental sustainability. In Proceedings of the Institution of Civil Engineers-Civil Engineering, 161(5), 21-24. Thomas Telford Ltd. https://doi.org/10.1680/cien.2007.161.5.21

Lorenzo, G. A., Bergado, D. T., Bunthai, W., Hormdee, D., \& Phothiraksanon, P. (2004). Innovations and performances of PVD and dual function geosynthetic applications. Geotextiles and Geomembranes, 22(1-2), 75-99.

https://doi.org/10.1016/S0266-1144(03)00053-0

Martin-Domingo, L., \& Martín, J. C. (2016). Airport mobile internet an innovation. Journal of Air Transport Management, 55, 102-112. https://doi.org/10.1016/j.jairtraman.2016.05.002

Mayer, C. (2019). Digital passengers: A great divide or emerging opportunity? Journal of Airport Management, 13(4), 335-344.

Mayer, R. H., Zondervan, D. J., Crow, B. M., Allerdice, J. K., \& Walton, H. M. (2015, April). Development and operational transition of the first PBN-enabled departure separation standard. In 2015 Integrated Communication, Navigation and Surveillance Conference (ICNS) (pp. I2-1-I2-10). IEEE. https://doi.org/10.1109/ICNSURV.2015.7121301

Mayring, P. (2004). Qualitative content analysis. A Companion to Qualitative Research, 1(2004), 159-176.

Medvedev, A., Alomar, I., \& Augustyn, S. (2017). Innovation in airport design. Aviation, 21(1), 23-28. https://doi.org/10.3846/16487788.2017.1303542

Melníkova, L., Jenčova, E., Vajdova, I., Korba, P., \& Hovanec, M. (2018). Project proposal for the introduction of sleeping boxes at the istanbule airport. In Transport Means 2018 - Proceedings of the International Conference (pp. 1482-1486). Latvia.

Merriam-Webster. (2017, March). Innovation. https://www.merriam-webster.com/dictionary/innovation
Mirza, Z. R. F., \& Brohi, M. N. (2013). Smart travelling with radio frequency identification. Journal of Computer Science, 9(12), 1734-1737. https://doi.org/10.3844/jcssp.2013.1734.1737

Möller, D. P., Vakilzadian, H., \& Deutschmann, A. (2018, May). Intelligent system demonstrator for secure luggage handling. In 2018 IEEE International Conference on Electro/Information Technology (EIT) (pp. 0701-0706). IEEE. https://doi.org/10.1109/EIT.2018.8500248

Negri, N. A. R., Borille, G. M. R., \& Falcão, V. A. (2019). Acceptance of biometric technology in airport check-in. Journal of Air Transport Management, 81, 101720.

https://doi.org/10.1016/j.jairtraman.2019.101720

Neto, R. F. M., Paris, L. E., Junior, F. A., \& Mendes, K. P. (2019). The management of environmental services in Brazilian public airports: The challenges in searching for efficiency. Environmental Science \& Policy, 100, 1-7. https://doi.org/10.1016/j.envsci.2019.05.025

Niine, T., Kolbre, E., \& Miina, A. (2017). Enablers and constraints of peripheral air cargo - A case study of Estonia. Journal of Air Transport Management, 61, 106-114. https://doi.org/10.1016/j.jairtraman.2016.07.001

Organisation for Economic Cooperation and Development. (2005). Oslo Manual: guidelines for collecting and interpreting innovation data (3rd ed.). In The Measurement of scientific and technological activities. OECD Publishing. https://doi.org/10.1787/9789264013100-en

Organisation for Economic Cooperation and Development. (2018). Oslo Manual 2018: Guidelines for collecting, reporting and using data on innovation. OECD.

Oostveen, A.-M., Kaufmann, M., Krempel, E., \& Grasemann, G. (2014). Automated border control: a comparative usability study at two European airports. In 8th International Conference on Interfaces and Human Computer Interaction (IHCI 2014). Lisbon, Portugal. https://doi.org/10.2139/ssrn.2432461

Palinkas, L. A., Horwitz, S. M., Green, C. A., Wisdom, J. P., Duan, N., \& Hoagwood, K. (2015). Purposeful sampling for qualitative data collection and analysis in mixed method implementation research. Administration and Policy in Mental Health and Mental Health Services Research, 42(5), 533-544. https://doi.org/10.1007/s10488-013-0528-y

Pat-El, I., \& Orshan, O. M. (2015). The international space center Ashdod - ISC (israel). In the Proceedings of the International Astronautical Congress, IAC, 13, 10276-10280.

Patton, M. Q. (2002). Two decades of developments in qualitative inquiry: A personal, experiential perspective. Qualitative Social Work, 1(3), 261-283. https://doi.org/10.1177/1473325002001003636

Pica, A., Pica, M., Ficai, D., Ficai, A., \& Florica, D. (2015). Incorporation of silver nanoparticles in film forming materials for long term antimicrobial action. Current Nanoscience, 11(6), 760-769. https://doi.org/10.2174/1573413711666150615221722

Pitt, M., \& Tucker, M. (2008). Performance measurement in facilities management: driving innovation? Property Management, 26(4). https://doi.org/10.1108/02637470810894885

Prahalad, C. K., \& Ramaswamy, V. (2003). The new frontier of experience innovation. MIT Sloan Management Review.

Price, R., Wrigley, C., Matthews, J. H., \& Dreiling, A. (2014). A digital airport experience: design-led innovation in support of airport strategy. In Proceedings of 19th DMI: Academic Design Management Conference (pp. 2710-2729). The Design Management Institute.

Radaha, T. R., \& Johnson, M. E. (2013). Mobile indoor navigation application for airport transits. Purdue University. 
Ryley, T., Elmirghani, J., Budd, T., Miyoshi, C., Mason, K., Moxon, R., Ahmed, I., Qazi, B., Zanni, A. (2013). Sustainable development and airport surface access: the role of technological innovation and behavioral change. Sustainability, 5(4), 1617-1631. https://doi.org/10.3390/su5041617

Santos, M., Manikonda, V., Feinberg, A., \& Lohr, G. (2008, August). A simulation testbed for airborne merging and spacing. In AIAA Modeling and Simulation Technologies Conference and Exhibit (p. 6345). American Institute of Aeronautics and Astronautics. https://doi.org/10.2514/6.2008-6345

Schilling, J. (2006). On the pragmatics of qualitative assessment: Designing the process for content analysis. European Journal of Psychological Assessment, 22(1), 28-37. https://doi.org/10.1027/1015-5759.22.1.28

Schmidt, S., Zierath, F., Amann, H., \& Meyer, H. (2012). The taxiway bridges of the new runway northwest at the airport Frankfurt/Main. Beton-und Stahlbetonbau, 107(3), 164-174. https://doi.org/10.1002/best.201100084

SCImago. (n.d.). SJR - SCImago Journal \& Country Rank. http:// www.scimagojr.com

Silvester, S., Beella, S. K., Van Timmeren, A., Bauer, P., Quist, J., \& Van Dijk, S. (2013). Exploring design scenarios for largescale implementation of electric vehicles; the Amsterdam Schiphol case. Journal of Cleaner Production, 48, 211-219. https://doi.org/10.1016/j.jclepro.2012.07.053

Sinha, A. K., \& Jha, K. N. (2019). Financing constraints of public-private partnership projects in India. Engineering, Construction and Architectural Management, 28(1). https://doi.org/10.1108/ECAM-06-2018-0237

Smith, E., \& Ugolini, M. (2017, September). Building information and communication technology (ICT) value-propositions for the post-information age. In 2017 56th FITCE Congress (pp. 1-9). IEEE. https://doi.org/10.1109/FITCE.2017.8092999

Soepnel, S., \& Roling, P. C. (2017). Impact of electric taxi systems on airport apron operations and gate congestion. In 17th AIAA Aviation Technology, Integration, and Operations Conference (p. 4391). AIAA. https://doi.org/10.2514/6.2017-4391

Sproule, W. J. (2001). A look back at the development of automated people mover systems. In Automated People Movers: Moving Through the Millennium (pp. 1-9). ASCE. https://doi.org/10.1061/40582(2001)2

Sproule, W. J. (2009). Somewhere in time - a history of automated people movers. In Automated People Movers 2009: Connecting People, Connecting Places, Connecting Modes (pp. 413-424). ASCE. https://doi.org/10.1061/41038(343)35

Stock, R. M., \& Zacharias, N. A. (2011). Patterns and performance outcomes of innovation orientation. Journal of the Academy of Marketing Science, 39(6), 870-888. https://doi.org/10.1007/s11747-010-0225-2
Straker, K., \& Wrigley, C. (2018). Engaging passengers across digital channels: An international study of 100 airports. Journal of Hospitality and Tourism Management, 34, 82-92. https://doi.org/10.1016/j.jhtm.2018.01.001

Taran, Y., Boer, H., \& Lindgren, P. (2015). A business model innovation typology. Decision Sciences, 46(2), 301-331. https://doi.org/10.1111/deci.12128

Thomas, A. R., Pop, N. A., Iorga, A. M. \& Ducu, C. (Eds.). (2016). Ethics and neuromarketing: Implications for market research and business practice. Springer. https://doi.org/10.1007/978-3-319-45609-6

Tidd, J. \& Bessant, J. (2013). Integrating technological, market and organizational change (5th ed.). Wiley.

Ucler, Ç., \& Martin-Domingo, L. (2015). Traveler's idle time and the value chain at airports. Journal of Aeronautics and Space Technologies, 8(2), 25-33. https://doi.org/10.7603/s40690-015-0013-9

Ueda, K., \& Kurahashi, S. (2016, November). The passenger decision making mechanism of self-service kiosk at the airport. In JSAI International Symposium on Artificial Intelligence (pp. 159-175). Springer, Cham.

https://doi.org/10.1007/978-3-319-61572-1_11

White, G. (2017, August). Towards a performance-based airport asphalt specification. In Proceedings of the International Conference on Highway Pavements and Airfield Technology 2017 (pp. 1-14). American Society of Civil Engineers. https://doi.org/10.1061/9780784480953.001

Wong, D., Pitfield, D., Caves, R., \& Appleyard, A. (2006). The development of aircraft accident frequency models. In C. Guedes Soares \& E. Zio, Safety and reliability for managing risk: Proccedings of the European Safety and Reliability Conference (ESREL 2006), Vol. 1 (pp. 18-22). Taylor \& Francis.

Yu, T. Y., \& Huang, P. T. (2014). Border innovation management, improved passenger services and satisfaction acceptance. International Journal of Process Management and Benchmarking, 4(1), 89-108. https://doi.org/10.1504/IJPMB.2014.059455

Zamawe, F. C. (2015). The implication of using NVivo software in qualitative data analysis: Evidence-based reflections. $\mathrm{Ma}$ lawi Medical Journal, 27(1), 13-15. https://doi.org/10.4314/mmj.v27i1.4

Zhang, T., Ouyang, Y., \& He, Y. (2008). Traceable air baggage handling system based on RFID tags in the airport. Journal of Theoretical and Applied Electronic Commerce Research, 3(1), 106-115. https://doi.org/10.3390/jtaer3010011 